\title{
Rural Roads and Agricultural Development in Swaziland
}

\author{
Lindsay A. K. \\ University of Swaziland, Department of Political and Administrative Studies \\ Kwaluseni Campus, Private Bag 4, Kwaluseni M201. Swaziland \\ Tel: 268-2517-0408_E-mail: alindsay@uniswa.sz \\ Mukole Kongolo (Corresponding author) \\ University of Swaziland, Department of Economics \\ Kwaluseni Campus, Private Bag 4, Kwaluseni, M201, Swaziland \\ Tel: 268-2517-0233Ｅ-mail: gilkoka8@gmail.com
}

Received: September 11, 2014 Accepted: November 4, 2014 Published: November 6, 2014

doi:10.5296/jsss.v2i1.6561ＵRL: http://dx.doi.org/10.5296/jsss.v2i1.6561

\begin{abstract}
The objective of this study was to examine the importance of managing and maintaining the quality of rural roads to support agricultural and rural development in the Kingdom of Swaziland, to facilitate the distribution of agricultural products and its accessibility to the population. A structured questionnaire survey was used to collect both secondary and primary data sources, to fill the key information gaps through random sampling method. The data collected were tabulated and analysed through Excel programme on the Microsoft programme. The findings revealed that local residents were not exposed to new and dynamic flow of opportunities that can enhance their livelihood by providing them with better access to education, medical facilities and markets through rural roads. The study concluded that rural roads are critical in supporting both rural and agricultural development for improved socio economic conditions of the people.
\end{abstract}

Keywords: Rural infrastructure, Rural transport, Transport costs, Agricultural growth, Resource modernisation, Swaziland 


\section{Introduction}

Without physical access, rural communities face obstacles in social services delivery such as health, education, and related social services (Escobal \& Ponce, 2002). Evidence suggests that rural communities can be mobilised to manage and maintain their access roads if some financial incentives and an appropriate legal framework are made available by the government (IFRTD, 2006). Poverty, isolation, mobility and accessibility have been considered the overriding objective of donors, with great emphasis on maximising economic growth, as the difference between rich and poor increases rather than decreases. Poverty is at the same time a simple reality and a complicated concept, we often know it when we see it, but when we try to define it, the precision becomes more and more elusive (Dercon et al., 2009). Mobility defines the way in which people can access goods and services. The need for mobility becomes easy when services are moved closer to the consumers. One of the ways to make services more accessible is by making people more mobile through roads (ADB, 2006). Accessibility defines how easy or difficult is it to get to a place. A place is accessible when people can reach there in an acceptable time, and the risk of not getting there on time would be heavy (Tighe, 2006).

Rural community's ability to take advantage of surplus crop production and employment opportunities is severely reduced. Rural roads play a role in the provision of physical access. Physical access further plays an important role in reaching a number of the Millennium Development Goals (Barret et al., 2001). The benefits of improved access can be short lived if the rural roads are not managed and maintained. In most instances rural roads are defined as those roads with less than 50 vehicles a day, ranging from engineered roads and bridge that link to towns and villages, to motorable tracks, trails and paths. In general these roads serve dispersed households and populations, often with an agricultural or natural resource based land use structure (Donngos et al., 2007). Rural road networks also tend to be large and complex; they are often 2 to 3 times the size of the main and regional networks, but carry only $10 \%$ of the traffic in vehicle kilometres (IFRTD, 2006). Foot, animal and bicycle paths also feed into rural roads; in turn rural roads link markets and peri-urban hubs (Fouracre \& Dyson, 2006). Rural roads include secondary roads and any other roads used by communities in urban and rural areas than main roads, and are managed by various municipalities. They are generally managed by local governments and communities. They account for about $80 \%$ of the total road network lengths but carry only $20 \%$ of the total motorized traffic. They provide access to the majority of population in most rural areas in the country. Traffic in these roads often consists of a majority of non-motorized or intermediate means of transport and pedestrians. Management and financing arrangements for these roads are often scarce and sometimes are not in existence (Buys et al., 2006).

Often the term rural transport infrastructure is used to ensure that tracks, paths and footbridges are included in the considerations. To understand issues with rural road management it is necessary to understand the decentralisation context in the various countries. Also, to assist decision making on improved management arrangements for rural roads it is necessary to get to know the extent and condition of the rural road network. Furthermore, it will be important that transport policies take into account rural transport issues in general, and that the legal context for the management and financing of rural roads is clearly defined in the country's road legislation or Roads Act (Buys et al., 2006). Rural roads and transport are essential for 
sustaining agricultural development. Despite considerable past investments, the burden of managing and maintaining African roads is still high as many roads remain rough and impassable throughout the years (Donngos et al., 2007).

Many rural Africans still suffer from poor access to markets, health, schooling, and high transport costs (World Bank, 2000). Inadequate rural roads make it hard for farmers to produce more and to transport any surpluses after harvest. Traffic on most rural roads still consists mainly of pedestrians often carrying head loads. African governments have relied on private truck fleets for crop transport (DFID, 2008). Rural infrastructure cannot be created by peasants themselves, because most villages have no businesses or enterprises and have no money to spend on infrastructure. As most villages contribute to urban and industrial development by selling cheap agricultural goods, it is time for the urban economy and industrial sector to give something back to rural villages (Zhao \& Kanamori, 2007; Easterly, 2001).

\subsection{The problem}

Agricultural production by small-scale farmers in Swaziland has its final destination to main centres of the country, where it is distributed to various local markets. About 3/4 of the rural roads in the study area are in poor conditions and need to be repaired. The lack of adequate rural infrastructure in the country has affected food production and distribution drastically. This in return can create food shortages in the main centres, where food demand is very high. Poor and inadequate rural roads have been the main concern by both small producers and consumers. Urgent response to this problem would be: (i) to improve the state of the existing rural roads, and (ii) to construct new rural roads in places where basic infrastructure is desperately needed. That is, to construct rural roads between farms and markets to increase connections between producers and consumers (Riverson \& Carapetis, 1991). Rural Africa has only $34 \%$ of road access covered as compared to $90 \%$ in the rest of the world (AFDB, 2010). The state of the existing infrastructure is generally very poor because governments are unwilling to spend the amount of money required to keep roads in basic repair. This compounds the high poverty and low food security levels in most Sub-Saharan Africa, impairing the distribution of food, farmer connections to market, information exchange, and intra-trade. Many areas in these countries are poor, a condition which fosters inadequate infrastructure, construction, maintenance and management (Gannon \& Lui, 1997). Poverty in these areas is increased because of isolation caused by lack of infrastructure (Corral \& Reardon, 2001; Easterly, 2001; Deichmann et al., 2006). A regional network upgrading would help bring Swaziland out of poverty trap, expanding overland trade by about $\$ 250$ billion over 15 years, with "major direct and indirect benefits for rural population (Buys et al., 2006).

The country should first examine the quality of rural roads, quantified by quality index that takes into account the percent of roads that are paved and the country's GDP. After the quality of the road has been assessed, the minimum quality road index of up to 45 will be required, to improve road quality in the country. This would increase trade and thus GDP, as well as making food distribution easier and more effective. The improvement should apply to main roads, connecting all major centres. Furthermore, with the expected increase in trade and GDP that will result in this process, the country will be able to start upgrading secondary and smaller rural roads. After initial upgrades, it is also important that roads are kept up with yearly maintenance. Not only will this make transportation easier, but it will also save a significant 
amount of money (Guimaraes \& Uhl, 1997; Isotalo, 1992; Jacoby, 2000). Rural roads are often seen as key to raising living standards in poor rural areas. Yet despite the consensus on their importance and much anecdotal evidence, there is surprisingly little hard evidence on the size and nature of their benefits (World Bank, 2005).

This study aims to assess the impact of rural roads in contributing to agricultural development in the Kingdome of Swaziland. It also contributes to policy discussions on how best to allocate scarce public resources to meet the people's need. This study is organized as follows: section 2 presents methodology, section 3 focuses on rural roads and food distribution in Swaziland (rural mobility), section 4 presents improving, managing and constructing new rural roads, and section 5 provides conclusion and recommendations.

\subsection{Objective}

The main objective of this study was to examine the importance of maintaining the quality of rural roads to support agricultural development, by making food distribution easier and more effective.

\subsection{Limitations of the Study}

In terms of the present study, it was important that we restrict our discussion to the role of rural roads in creating socio economic development opportunities in rural Swaziland. That is, to the research problem under investigation with emphasis on the following: (i) Rural roads and food distribution in Swaziland; (ii) Focus on rural mobility; and (iii) Improving, managing, maintaining or construction of new roads.

\subsection{Conceptual Framework and Research Design}

While the existing literature points to the deep impact that rural roads have on rural community's lives, there is nonetheless a scarcity of research on this issue and its outcomes in the country's rural areas. For this reason, this study is aimed at showing the important role of rural roads in the socio-economic and cultural development of any region. The general consensus is that the interventions in the form of rural roads has wide potential to reach and enhance that sector of rural population which has been persistently marginalized from the benefits of aggregate economic growth. This study attempts to address the void and disentangle the degree of those impacts. To address this gap in the literature, this study was conducted to specifically explore the dynamism effects and outcomes of rural roads on rural community in Swaziland. For this study, the authors employed a combination of qualitative methods, to investigate the importance of managing rural roads for agricultural development in Swaziland. Random sampling method was used in data collection. The participants represented rural people in three different areas of the study.

\section{Methodology}

This study is a result of the analysis of information collected through a number of ways. Considering the fact that there can be number of sources to gather information, the methodology adopted in this study represents relatively a cost effective approach. The first step involved a thorough review of related literatures such as published and unpublished reports, rural road studies, articles, policy documents, as well as reports of programs and road infrastructures related studies on Africa. In this way the primary phase of study made effective use of information already available while conceptualizing this assessment, thus 
being able to focus on data collection to fill only the key information gaps. The study methodology was carefully designed to maximize the use of qualitative information available.

\subsection{Study Area}

Swaziland, officially the Kingdom of Swaziland, and sometimes called Ngwane or Swatini, is a landlocked country in Southern Africa, bordered to the north, south, west and east by South Africa, and to the north by Mozambique. The nation, as well as its people, are named after the 19 th century king Mswati II. The country is situated approximately between latitudes 260 and 280 South and longitude 310 and 320 East. It covers an area of about 17,000 $\mathrm{km}^{2}$ and it has a population of approximately 1,200,000 inhabitants (World Atlas, 2014). It is a country of rolling grassy hills and pine forests covering mountains reaching up to 4,500 feet above sea level. It is the home of the Swazi, a group-oriented, Bantu-speaking people of Nguni descent who settled in the region of what is today Maputo in Mozambique around 1600 (Sosou et al., 2011). The study areas consist of Manzini, Siteki and Big Bend where the main agricultural activities are concentrated. Main crops include maize, sugar cane and beans. Chickens, ducks, goats, sheep and cattle are raised for meat and the diet is also supplemented by wild game and fish. Small-scale farmers dominate the production of the staple food crops. Women generally handle food production, transport to markets, and sale (Calvo, 1994). However, rural roads impact negatively on the lives of the farmers by rendering them very miserable (Sossou et al., 2011). ch of needed food to urban areas, although food imports have been increasingly playing an important role for the swelling urban population.

\subsection{Sources of Data}

This was a desk research review of the available literature on rural roads management and maintenance. Structured questionnaire was used to focus on data collection to fill the key information gaps through random sampling method. Direct observation method was applied while collecting the primary data. Households were asked about general information, change in the access to different aspects of socio-economic life such as employment, possession of assets and amenities, production of agricultural goods, use of different social services and ease in access to them and negative benefits as well, and mode of transport used. The rural household survey method covers 96 households selected from the study area. A random sampling method was used to select households in the area. Both primary and secondary sources of information were obtained through a document methods study. The data were tabulated and analysed through Excel programme. This paper investigates the importance of rural roads in supporting agricultural development in the Kingdom of Swaziland based on both primary secondary sources (Baily, 1994; Baker, 1998). The examination of these various sources assisted to look into the various issues on rural roads in Swaziland holistically.

\section{Results and Dicussion}

\subsection{Rural Roads and Food Distribution in Swaziland}

According to FAO (2000), the available data on food supply and requirements in Swaziland estimated to be in deficit. Food aid currently being provided targets the most vulnerable groups such as children and the elderly, while the hungry poor must fend for themselves. The coping mechanisms such as eating less food, having fewer meals and growing vegetables in household compounds have been stretched to the limit. The main factors constraining food supply include 
the extreme state of roads linking to main centres and other such as traders and farmers as well as the cost of fuel (Limao \& Venable, 2000; Longo \& Sekkat, 2004). While revamping the whole transport infrastructure is a long term endeavour, donors could assist the Government to urgently repair critical sections of main roads leading to main centres, with priority given to the Mbabane, Manzini, Nhlangano, Big Bend and Siteki. This will be a major step towards restoring the normal flow of foodstuffs to the major centres. In addition, assistance to regional authorities and local communities for feeder road management and maintenance should be substantially increased (FAO, 2000). The agricultural sector in Swaziland needs to change by tackling road infrastructures. The government should try to reform this sector through mechanization, new market opportunities for small-scale farmers and land expansion, because they are the majority in the country. It should improve a competitiveness of the national agriculture by creating self-sufficiency in food production. Thirty years ago, very few African countries were dependent on food imports. Presently, even though some African countries celebrated their 50 years of independence, it is true that no one of them is independent from food self-sufficiency and nutritional standpoint. Swaziland should strategise on farm mechanization, create new market opportunities for small-scale farmers and restructure its national tradition through innovation and improved yields for self-sufficiency in food (Africa Avenir, 2010). The current road network in Swaziland is divided into four broad categories of roads, as shown in Table 1.

Table 1. The four broad categories of roads in Swaziland

\begin{tabular}{llll}
\hline Category of road & Paved km & Unpaved km & Total km \\
\hline Main roads & 852 & 539 & 1392 \\
District roads & 62 & 1534 & 1596 \\
Urban roads & 200 & 188 & 388 \\
Feeder roads & - & 1500 & 1500 \\
Total & 1114 & 3761 & 4876 \\
\hline
\end{tabular}

Source: Swaziland Road Reform study.

Road network management responsibilities lie with the Local authorities, that is, municipalities, Town Road Boards and town councils, and the Roads Department in the Ministry of works manage the road network in Swaziland. The Roads Department is responsible for the main and district roads as well as the feeder roads, in other words they are responsible for the bulk of the road network as shown in the table 1 above. Well managed and maintained road network can enhancing the country's trade competitiveness through spillover effects of road network.

\subsection{Focus on Rural Mobility}

Development partners should focus on rural mobility to learn and understand how to achieve better aid effectiveness in rural transport. So far, most development partners and governments in Africa have relied on two overarching assumptions, which have led to massive road investments by being ineffective: 
(i) most households in rural areas of Africa are not connected to markets and therefore need passable roads for a truck because they are remote, (ii) roads with a high level of service are crucial to achieve high economic impact. These roads should be for trucks including others secondary road networks, which link to cities. As such, they should be in good conditions (paved or unpaved) to enable truck fleet efficiency and competition. Donor coordination is very important to avoid the rehabilitation of rural roads not connected to passable secondary roads (Raballand, 2010). In terms of how both men and women access goods and services, it is important to fill in the gaps in our knowledge about how they are being affected in accessing these goods and services, which influence the provision of transport infrastructure (Porter 2002). Rural road networks should aim to maximise the participation of both men and women in development of rural communities, create development opportunities by involving those working on rural transport (IFRTD, 2005).

\subsection{Improving, Managing, Maintaining and Construction of New Roads}

Road access of low percentage (34\%) reflects the lack of infrastructure in African countries, especially in Sub-Saharan Africa. Only about $25 \%$ of the people in rural areas have access to market within two hours (WFP, 2009). Despite this, national programs and organization still tend to focus mainly on the construction of major roads, because small rural roads have a smaller economic impact. This can be addressed by employing cheap local labour to construct rural roads connecting farms and markets. The strategy will require that local labour or farmers working on these road projects receive incentives in return for their labor as part of the project. Local labour (women in the majority) can be used because it solves the problem of delivering equipment due to the lack of infrastructure in many rural areas, as it is almost impossible to move in big machines to these areas (Bryceson \& Howe, 1993). Given that building roads requires mainly physical work, it is important to know how women could also contribute to this type of work. Johannessen (2008) argues that this is an effective method in which the local people can build rural roads, but the only issue in this will be the experts who plan the construction and teach people how to construct the roads. The construction of roads can begin with local materials/resources at the local villages, as the delivery of the necessary materials will depend on how fast roads can be built in a most cost-effective way (Johannessen, 2008). Another problem which is dominant in most rural areas of Africa is the lack of cheap transportation. Evidence shows that even in places where roads exist with little access to bus, taxi or matatu systems, people still have to walk a long distance to get access to those means since the systems are often not developed enough (Jacoby, 2000).

Walking is the most important form of non-motorised transportation. Other forms of non-motorised include bicycle, human porterage, wheelbarrow, and animal drawn cart. Generally, non-motorised transport includes any form of transportation that provides personal or goods mobility by methods other than the combustion motor (Guitink et al., 1994). Time and energy involved in off-road transport are major constraints to any efforts by rural communities to move from one place to another. Based on experience from other African countries such as Burkina Faso, Ghana, Uganda Rwanda, Kenya, and Malawi, this study provides an alternative low-cost intermediate means of transport which can provide a level of improvement in rural transport. It is expected that it will affect travel for social and economic purposes that is rarely achieved through road improvements alone. In this way, farmers can be provided with 
adequate means of transportation, such as a bicycle with a trailer and others to improve the efficiency on directly productive tasks (Riverson \& Carapetis, 1991).

Table 2 provides alternative intermediate means of transport to improve the efficiency of productive task and serve as a bridge between rural areas

\begin{tabular}{llll}
\hline Type of intermediate transport & $\begin{array}{l}\text { Max Load } \\
(\mathrm{Kg})\end{array}$ & $\begin{array}{l}\text { Max Speed } \\
(\mathrm{Km} / \mathrm{h})\end{array}$ & $\begin{array}{l}\text { Max Range } \\
(\mathrm{Km})\end{array}$ \\
\hline Wheelbarrow & 100 & 5 & 10 \\
Bicycle & 75 & 20 & 20 \\
Bicycle with trailer & 200 & $10-15$ & $15-20$ \\
Bicycle and sidecar & 150 & $10-15$ & $15-20$ \\
Pack animal & $100-250$ & 5 & $15-20$ \\
Animal-drawn cart (Oxen) & $500-1500$ & 5 & $15-20$ \\
Motorcycle & 100 & $40-90$ & 100 \\
Motorcycle and sidecar & $250-500$ & $30-60$ & 60 \\
Motorcycle and trailer & 250 & $30-60$ & 6 \\
Single-axle tractor and trailer & 1500 & $15-20$ & 40 \\
\hline
\end{tabular}

Source: study information 2014.

In agricultural production, rural people rarely uses any kind of motor vehicule, they relies mainly on household labour, with time and energy-consuming in moving small loads over relatively short distances. The movement of the load consignments could suitably be undertaken using intermediate means of transport. They have high load capacities than head-loading, including high travel speeds than walking, and they significantly reduce the amount of time and energy spent walking and head loading (Riverson \& Carapetis, 1991).

This type of cheap means of transportation can assist farmers carry more products and does not require political or social infrastructure to implement, like in the case of vehicles or trains.

However, the obvious limitation to this suggestion is that it can be only implemented in areas with appropriate roads (Riverson \& Carapetis, 1991). The estimate cost of constructing rural roads in the country would be much more than the cost of providing bicycles with trailers small farmers, including the cost of purchase, shipping and maintenance tools such as oil. In order to meet these cost, it is expected the regional/provincial government to also contribute toward the financial requirements, because it is the main beneficiary in economic and social aspects of rural roads. The regional/provincial government backed by donor community's task will be to ensure that farmers' contribution for building rural roads would not be high and also that they have not to suffer from hunger and poverty. This can be seen as a short-term solution until the regional/provincial government will improve, manage and maintain rural roads for higher GDP. Such action can raise regional GDP by more margin (Buys et al., 2006). 


\section{Conclusion and Recommendations}

\subsection{Conclusion}

The main objective of this study was to examine the importance of managing and maintaining the quality of rural roads to support agricultural development and related socio-economic activities, and to make food distribution easier and more efficient in the Kingdom of Swaziland. Many studies have shown that rural roads are critical in increasing economic activities that increase rural income. They are often treated as the least link of the transport network, and often form the most important link in terms of providing access for rural population. The lack of management impacts negatively on access of rural communities to basic services. Whether one looks at agriculture or rural migration to urban, rural roads still play an important and a useful role. Constructing a road in rural area would be more expensive than managing and maintaining the existing ones. Constructing a road alone does not help much rural communities, because transportation costs and economic conditions of the communities matter most.

Transportation costs will need to be subsidised by government, consequently without a subsidized motorised transport in rural areas, communities will prefer to still walk or either use cycle or both. Reducing the transport burden for rural women can release time and energy for productive and socially beneficial activities. The magnitude of the transport burden incurred by rural women to obtain access to domestic facilities is huge. The only way is to improve access to these facilities in order to alleviate the burden of social activities on women. This study considered rural roads as catalyst which aims at better crops, increased rural income, job creation and improvements in standard of life.

The study argues that improving rural roads increases welfare of the people, develop better facilities for rural way of life, creates values by improving marketing and storage facilities. Overall, in this thoughtful study, the economic development was in focus, and in order to get the people out of poverty, it requires multiple solutions and multiple approaches. Finally, the lessons learned from the literature on rural roads studies in Africa have shown systematic shortcomings due to insufficient focus on road management, maintenance and community involvement.

\subsection{Recommendations}

Management and regular maintenance of rural roads is a critical pre-condition for sustaining the positive impact that rural roads can bring to rural communities. Minor maintenance should not often be neglected because of lack of funds or little political willingness. Instead, politicians should strategise to authorise small and major rehabilitation of roads or reconstruction should take place after the road has deteriorated. Problems with rural roads management and maintenance, which generally stem from lack of funds, are exacerbated when the institutional responsibility for rural roads is not clear, because the budget source for maintenance has not been properly established. In practice this type of lack of clarity should be often avoided. Full community participation and management should be recognised as important for long-term sustainability of infrastructure investment. When community management means cash or labour contributions, the burden should not fall only on the poor by being forced to contribute free labour. 


\section{References}

ADB. (2006). When do rural roads benefit the poor and how? An In-depth Analysis Based on Case Studies Hemamala Hettige. http://www.ecology.ethz.ch/education/TRE_content/Rural_roads_and_poverty.pdf AFDB. (2010). Infrastructure - African Development Bank. Retrieved on 22th August, 2011, from http://www.afdb.org/en/topics-sectors/sectors/infrastructure/

Afrique, A. (2010). Rural Roads are to support agriculture development in Congo Brazzaville. Bailey, K. D. (1994). Methods of social research (4th edition), New York, Free Press.

Barker, T. L. (1998). Doing social research, (4th edition) New York, Free Press.

Barret, C. B., Reardon T., \& Webb, P. (2001). Non farm income diversification and household livelihood strategies in rural Africa: concepts, dynamics and policy implications. Food Policy, 26, 315-331. http://dx.doi.org/10.1016/S0306-9192(01)00014-8

Bryceson, D. F., \& Howe, J. (1993). Rural household transport in Africa: Reducing the burden on women? World Development, 21, 1715-1728. http://dx.doi.org/10.1016/0305-750X(93)90079-O

Buys, P., Deichmann, U., \& Wheeler, D. (2006). Road Network Upgrading and Overland Trade Expansion in Sub-Saharan Africa. Development Research Group, World Bank. http://dx.doi.org/10.1596/1813-9450-4097

Calvo, C. M. (1994). Case study on the role of women in rural transport: Access of women to domestic facilities. Sub-Saharan Africa Transport Policy Program (SSATP Working Paper No11), The World Bank and Economic Commission for Africa.

Corral, L., \& Reardon, T. (2001). Rural non incomes in Nicaragua. World Development, 29(3), 427- 442 .

DFID. (2008). Better roads for Africa, Research News Research for Development. Retrieved on 19th August 2011, from http://www.dfid.gov.uk/r4d/news.asp?ArticleID=50292

Donngos, C, Edmonds, G., \& Johannessen, B. (2007). Rural roads maintenance: Sustaining the benefits of improved access. International Labour Organisation (ILO), Bangkok.

Dercon, S., Gilligan, D., Hoddinott, J., \& Woldehanna, T. (2009). The Impact of Agricultural Extension and Roads on Poverty and Consumption Growth in Fifteen Ethiopian Villages. American Journal of Agricultural Economics, 91(4), 1007-1021. http://dx.doi.org/10.1111/j.1467-8276.2009.01325.x

Easterly, W. (2001). The Elusive Quest for Growth: Economists' Adventures and Misadventures in the Tropics. Cambridge, MA: MI.T. (William R. Easterly: Books).

EISA. (2011). Electoral Institute for the Sustainability of Democracy in Africa. http://www.eisa.org.za/WEP/drc.htm

Escobal, J., \& Ponce, C. (2002). The benefits of rural roads: enhancing income opportunities for the rural poor. GRADE Working Paper 40-I, Lima, p. 52. Retrieved fromhttp://www.grade.org.pe/asp/brw_pub11.asp?id=486

FAO. (2000). Crop and food supply situation in Swaziland. FAO Corporate Document.

Fouracre, P. R., \& Dyson, M. (2006). Rural Roads. 
Gannon, C, \& Lui, Z. (1997). Poverty and transport. Washington, D C.: The World Bank INU/TWU Series Transport Publications. TWU-30.

Guimaraes, A. L., \& Uhl, C. (1997). Rural transport in Eastern Amazonia: limitations, options, and opportunities. Journal of Rural Studies, 13(4), 429-440. http://dx.doi.org/10.1016/S0743-0167(97)00019-3

Guitink, P., Holste, S., \& Lebo, J. (1994). Non-motorised transport: confronting poverty through affordable mobility. Infrastructure Notes, The World Bank. Transport No. UT- 4. Retrieved from: www.worldbank.org/INTURBANKTRANSPORT../T-UT-4.pdf

Jacoby, H. C. (2000). Access to markets and the benefits of rural roads. Economic Journal, 110(465), 713-737. http://dx.doi.org/10.1111/1468-0297.00562

Johannessen, B. (2008). Building Rural Roads. International Labor Organization.

IFRTD. (2005). Intermediate Means of Transport. The International Forum for Rural Transport and Development. Retrieved from http://ifrtd.gn.apc.org/new/issues/imts.php

Isotalo, J. (1992). Community participation in rural road maintenance: Finish experience and lessons for Sub-Saharan Africa. Infrastructure Notes. Transportation, Water and Development, Transport No. RD-13.

Limao, N., \& Venable, A. J. (2000). Infrastructure, geographical disadvantage, transport costs and trade. World Bank Economic Review, 15(3), 451-479. http://dx.doi.org/10.1093/wber/15.3.451

Longo, R., \& Sekket, K. (2004). Economic obstacles to expanding intra-African trade. World Development, 32(8), 1309-1321. http://dx.doi.org/10.1016/j.worlddev.2004.02.006

Mission. (2014). Feeding the World. Roads in Sub-Saharan Africa. Retrieved from http://12.000.scripts.mit.edu/mission2014/solutions/roads-in-sub-saharan-africa

Paudel, G. (2014). Influence of Roads on Socio-Economic Aspects of Rural People A case study of selected VDCs of Dailekh district. 3rd World Conference on Applied Sciences, Engineering \& Technology 27-29 September , Kathmandu, Nepal. Retrieved from http://www.basharesearch.com/WCSET2014/wcset2014048.pdf

Porter, G. (2002). Living in a walking world: rural mobility and social equity issues in Sub-Saharan Africar World Development, 30(2), 285-300. http://dx.doi.org/10.1016/S0305-750X(01)00106-1

Raballand, G. (2010). Rural Road Investment Efficiency: Lessons from Burkina Faso, Cameroon, and Uganda (Directions in Development), Synopses \& Reviews, Powell's Book. Annotation 2010 Book News, Inc., Portland, OR (booknews.com).

Riverson \& Carapetis. (1991). Intermediate Means of Transport In Sub-Saharan Africa. Its Potential for Improving Rural Travel and Transport (World Bank Technical Paper No 161 Africa Technical Department Series).

Sarkar, A. K. (2010). Key implementation issues- Sustainable rural roads maintenance in India. PIARC International Seminar, Hyderabad, Andhra Pradesh, India, 21-23 January.

Sossou, P., M'Paty, B., \& Buzika, F. (20110. Democatic Republic of Congo: Past. Present. Future? Civil society and the displaced persons of Bandundu. Coordinator and Accounts 


\section{Macrothink

Secretary of the BRP-Bandundu (Provincial Representation Bureau of the Independent Electoral Commission). Taken from www.fmreview.org/DRCongo/contents.htm

Tighe, D. (2006). Roads and Poverty Reduction. Paper presented at the International Seminar on Rural Road Transport, Siem Reap, Cambodia, 15-16 May. Retrieved from www.ruralroads.org/doc/roadsandpovertyreduction.pdf

World Atlas. (2014). Kingdom of Swaziland description. Retrieved from www.worldatlas.com/webimage/countrys/africa/sz.htm

World Bank. (2000). Rural roads in Philippines. Philippines - rural development \& natural resource management: trends, strategy implementation, and framework performance indicator system (Vol. 1 of 2): Main report.

World Food Programme. (2009). World Hunger Series, Hunger and Markets .

Zhao, Z., \& Kanamori, T. (2007). Infrastructure and regional development in the People's Republic of China. Tokyo Asian Development Bank Institute Discussion Paper No.69. Retrieved on 24th August 2011 , from http://www.adbi.org/discussion-paqper/2007/06/06/2279. prc.infra.rural

\section{Copyright Disclaimer}

Copyright reserved by the author(s).

This article is an open-access article distributed under the terms and conditions of the Creative Commons Attribution license (http://creativecommons.org/licenses/by/3.0/). 